Addressing drinking water salinity due to sea water intrusion in Praia de Leste, Parana, by a brackish water desalination pilot plant

Giovana Katie Wiechetecka,, Luiza Cintra Campos ${ }^{b}$, Gabriel Alfredo Carranzac, Miguel F. Acevedo ${ }^{d}$, Marcos Rogério Szeligaa, Mariana Espindola de Souzae, Tatiane Bovarotia, Ana Carolina Martins Rodriguesa, Juliano Penteado de Almeida , Ana Carolina Barbosa Kummer ${ }^{\mathrm{a}}$

-Post Graduation Programme of Sanitary and Environmental Engineering, State University of Ponta Grossa, 4748 Gal. Carlos Cavalcanti Av., Ponta Grossa, Paraná 84030-900, Brazil, Tel. +55 (42) 99109-1070; emails: giovana@uepg.br (G.K. Wiecheteck), marcosrs@uepg.br (M.R. Szeliga), tatianebovaroti@hotmail.com (T. Bovaroti), carol.rodrigues17@hotmail.com (A.C.M. Rodrigues), ja.julianoalmeida@gmail.com (J.P. de Almeida), ackummer@hotmail.com (A.C.B. Kummer)

'University College London, Gower St., WC1E 6BT, London, England, UK, email: Lcampos@ucl.ac.uk

-University of Louisiana at Lafayette, 600 McKinley Street, Lafayette, LA 70504-393, email: Gabriel@louisiana edu

“University of North Texas, 1155 Union Circle $\$ 310470$, Denton, TX 76203-5017, email: Miguel.Acevedo@unt.edu

'Water and Sanitation Company of Parana State, Rua Eng. Antonio Batista Ribas, 151 Curitiba, PR Brazil,

email: mariana.souza@sanepar.com.br

Received 13 November 2018; Accepted 3 July 2019

\title{
Addressing drinking water salinity due to sea water intrusion in Praia de Leste, Parana, by a brackish water desalination pilot plant
}

Giovana Katie Wiecheteck ${ }^{a^{*}}$, Luiza Cintra Campos ${ }^{\mathrm{b}}$, Gabriel Alfredo Carranza, Miguel F. Acevedod, Marcos Rogério Szeliga ${ }^{a}$, Mariana Espindola de Souza ${ }^{\mathrm{e}}$, Tatiane Bovarotia ${ }^{a}$, Ana Carolina Martins Rodrigues ${ }^{a}$, Juliano Penteado de Almeida ${ }^{a}$, Ana Carolina Barbosa Kummera

a Post Graduation Programme of Sanitary and Environmental Engineering, State University of Ponta Grossa, 4748 Gal. Carlos Cavalcanti Av., Ponta Grossa, Paraná 84030-900, Brazil; giovana@uepg.br (G.K.Wiecheteck); marcosrs@uepg.br (M.R.Szeliga); tatianebovaroti@hotmail.com (T.Bovaroti); carol.rodrigues17@hotmail.com (A.C.M.Rodrigues); ja.julianoalmeida@gmail.com (J.P.Almeida); ackummer@hotmail.com (A.C.B.Kummer)

b University College London. Gower St, London WC1E 6BT - London, England - UK; 1.campos@ucl.ac.uk

c University of Louisiana at Lafayette. 600 McKinley Street - Lafayette, LA 70504-393; Gabriel@louisiana.edu

${ }^{\mathrm{d}}$ University of North Texas.1155 Union Circle \#310470 - Denton, TX 76203-5017; Miguel.Acevedo@unt.edu

${ }^{\mathrm{e}}$ Water and Sanitation Company of Parana State. Rua Eng. Antonio Batista Ribas, 151 Curitiba, PR - Brazil; mariana.souza@sanepar.com.br

* Correspondence: giovana@uepg.br; Av. Carlos Cavalcanti, 4748 - CEP: 84030-900 Ponta Grossa - Parana - Brazil; Tel.: +55 (42) 99109-1070

Received: date; Accepted: date; Published: date 


\begin{abstract}
Seawater intrusion into the Pombas river, source of freshwater to Praia de Leste on the coast of Parana in Brazil presents a problem to the water utility as most water treatment plants in Brazil are conventional. To find a solution to this problem, a pilot plant $\left(1 \mathrm{~m}^{3} / \mathrm{h}\right)$ consisting of ultrafiltration (UF) followed by reverse osmosis (RO) was developed and evaluated. For testing, brackish water was produced with a concentration of 1,500 \pm 100 $\mathrm{mg} / \mathrm{L}$ of total dissolved solids (TDS), mixing seawater and fresh water. To evaluate the water quality, TDS, electrical conductivity, $\mathrm{pH}$, temperature, apparent color, turbidity, alkalinity, total hardness, calcium, chloride and sulfate were monitored. For operational performance, flowrates, osmotic pressure, filtration rate, recovery rate and mass balance were analyzed. On average, the UF system removed $96.4 \%$ of turbidity and $98.6 \%$ of apparent color; whereas the RO system removed $99.4 \%$ of TDS. The overall average recovery (UF and RO) was $45.81 \%$ with average osmotic pressure of 8.21 bar, filtration rate of $30.7 \mathrm{~L} / \mathrm{h} / \mathrm{m}^{2}$ in the UF system and $21.7 \mathrm{~L} / \mathrm{h} / \mathrm{m}^{2}$ in the RO system. From a water quality point of view, the system was effective in processing brackish into fresh water of high quality.
\end{abstract}

Keywords: brackish water; desalination; reverse osmosis; ultrafiltration. 


\section{Introduction}

Brackish and seawater desalination is increasingly common in arid and semi-arid regions and where freshwater availability is limited. Desalination is currently used in many countries and regions including but not limited to Australia, U.S.A., Japan, Spain, UK, in the MiddleEast, North Africa, and in sub-Saharan Africa (e.g. South Africa, Ghana). In Brazil, the Northeast region has only $3 \%$ of the country's water and which is mostly groundwater is accessed through about 100,000 drilled wells most of which contain brackish or saline water [1]. Such water is not suitable for human or animal consumption and has a low socio-economic value unless desalted. In addition, sea water intrusion into rivers and wells that supply fresh water to coastal populations is becoming an important issue facing water treatment plants responsible from capturing, treating and supplying fresh drinking water to their populations. The coast of the State of Parana in Southern Brazil is not exempted. The Water Treatment Plant of the Water and Sanitation Company of the Parana State (SANEPAR), located in the City of Praia de Leste uptakes water from the Pombas river to supply the local population. During the dry season, water supply from the river to the plant becomes brackish, possibly due to seawater intrusion into the Pombas river associated with its lower water flow. Because the current treatment plant is not equipped to reduce salinity of the water, the consumer would potentially receive potable water with concentrations above $1,000 \mathrm{mg} / \mathrm{L}$ of total dissolved solids (TDS), which exceeds the accepted limits of Brazilian standards for drinking water. When this happens, SANEPAR is forced to shut down the plant and transport water from other water treatment plants in the region. Additionally, there is a great interest to reduce the shortage of high quality potable water caused by the high consumption in coastal areas during summer and to avoid the reoccurrence of water scarcity problems such as those observed in Sao Paulo city [2].

Water desalination remains an important option for human use and consumption. Ultrafiltration (UF) and reverse osmosis (RO) are the most popular technologies for water desalination, and their costs have been reduced due to advanced developments [3]. Even so, the major challenges during desalination are still brine management and energy consumption.

The University of North Texas, (UNT), the University College London, (UCL) and the State University of Ponta Grossa, (UEPG), in partnership with SANEPAR, received funding from the Global Innovation Initiative (GII) of the US Department of State and the British Council to implement a sustainable pilot desalination plant composed of UF followed by RO, with the capacity to produce $1 \mathrm{~m}^{3} / \mathrm{h}$ of permeate, to explore solutions to the salt contamination of the drinking water. This project represents the first study of its kind in Brazil to address the growing problem of seawater intrusion in fresh water supplies through the experimental use of a sustainable brackish water desalination pilot plant. Because the frequent variability on water parameters of the supply from the Pombas river, another innovation was put into place by creating brackish water by mixing seawater with river water that arrives to the water treatment plant, to have a constant supply at a controlled salinity. Another aspect, was the incorporation of an additional coagulation step in the pretreatment, to control the variability of the water quality from the river. Although, the overall study focuses on addressing the three main issues of the use of desalination technology; the high cost of energy consumption, water quality and, brine disposal, this paper only presents the engineering design of the pilot plant, and the results of the studies related to performance of the system and water quality improvement.

\section{Materials and Methods}

\subsection{Study area}

Brazil has one of the most extensive coastlines in the world, with more than $8,500 \mathrm{~km}$. The Brazilian coast is home to around $26.6 \%$ of the country population. Parana state, with a 
population of 11,3 million [4], is one of the three states in the southern region with $98 \mathrm{~km}$ of coast extension. Praia de Leste, located in the Pontal do Parana County (Fig.1), has a population of 26,000 people [4] during the low touristic season. During the high season, between December and March, the population doubles or triples depending on the year. SANEPAR has a conventional water treatment plant with maximum capacity of $650 \mathrm{~L} / \mathrm{s}$ consisted of coagulation, flocculation, sedimentation, filtration and disinfection. The Pombas River is the major water source and has seawater intrusion problems in some periods of the year.
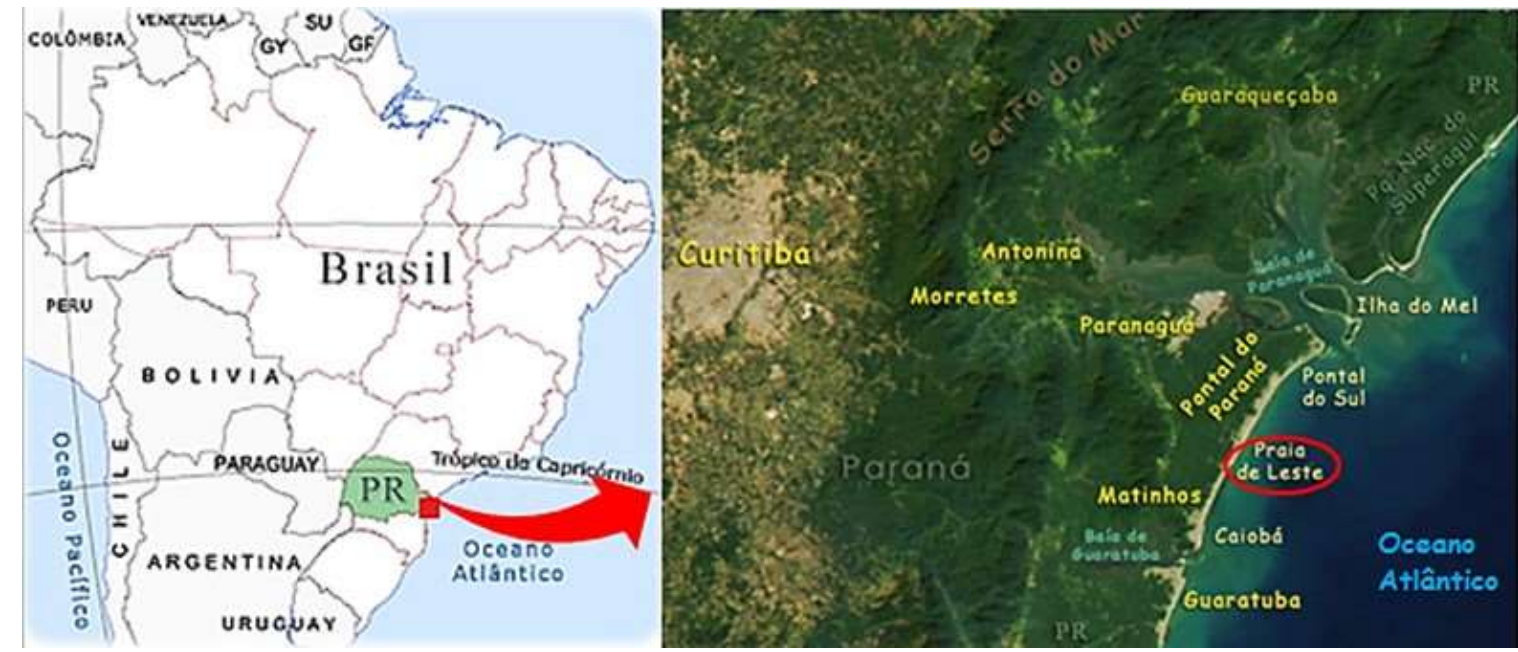

Fig. 1. Location map of Praia de Leste, coast of Parana State [adapted from 5].

\subsection{Engineering Design and Operation, brackish water desalination pilot plant}

The feed component of the pilot desalination system (Fig. 2) was composed of three tanks of $10,000 \mathrm{~L}$ to storage seawater, freshwater and brackish water equipped with pumps. For experimental purposes, seawater and freshwater are mixed to obtain brackish water. The UF system includes two tanks to store and dose coagulant (polyaluminium chloride) and sodium hydroxide (when necessary), control panel, centrifugal pump, disk filter, $\mathrm{pH}$ and turbidity meters, one vertical UF membrane of upflow, backwash pump, and permeate UF tank of 1,500 L. The RO system includes one disk filter, pressure pump, meters of redox potential, electrical conductivity, pressure and flow, two softeners and one tank for regeneration, three tanks to store and dose chemical products (anti-scaling, anti-fouling and sodium metabisulfite), static mixer, cartridge filter, high pressure pump, backwash pump, five horizontal RO membranes, CIP (i.e. clean in place) tank, ultraviolet disinfection, tank to storage and dose chlorine (was not used in the experiments), and control panel. Table 1 presents the characteristics of the UF and RO membranes, respectively. 


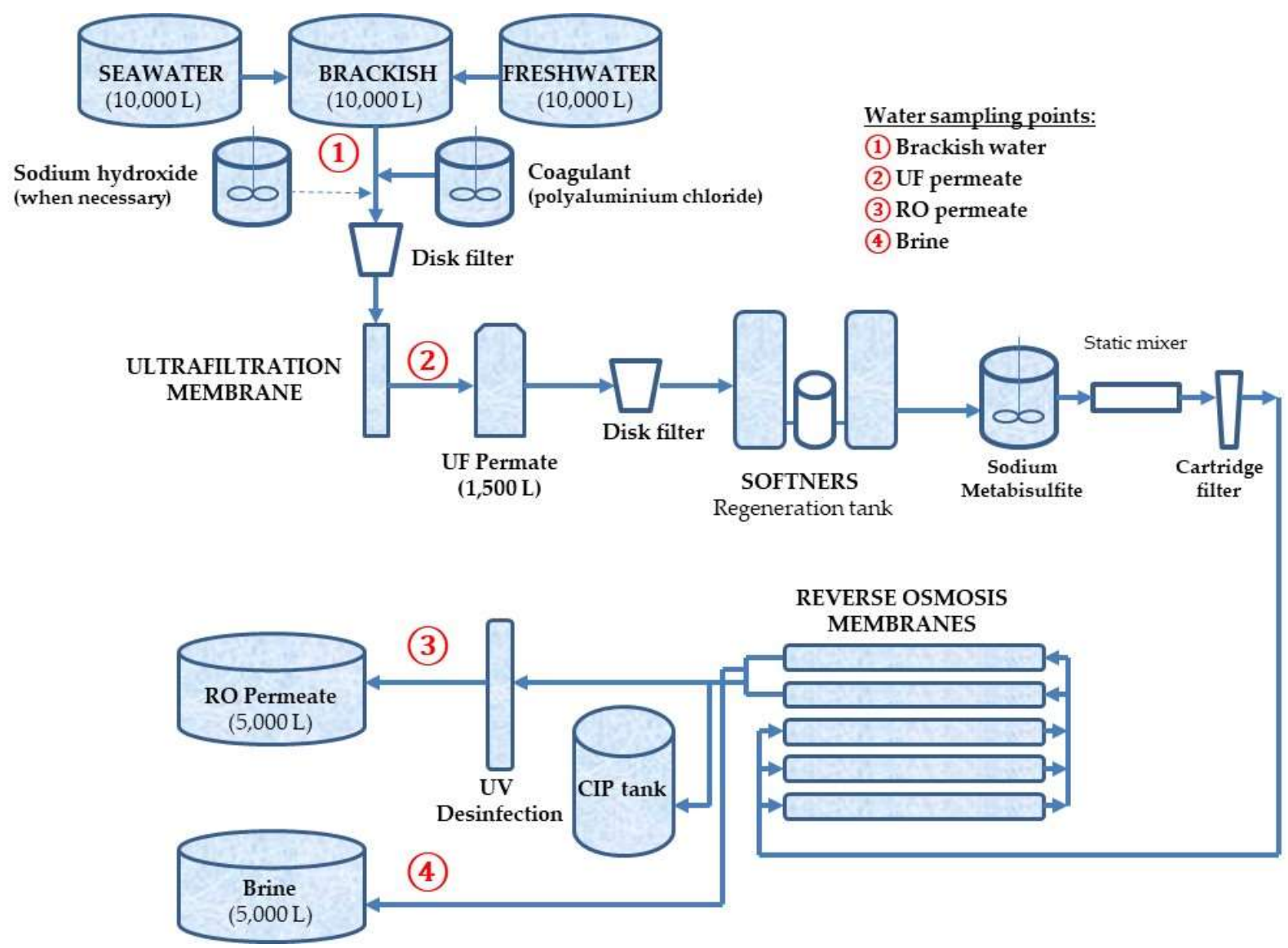

Fig. 2. Schematic diagram of the brackish water desalination pilot plant.

The capacity of the pilot desalination system was $1 \mathrm{~m}^{3} / \mathrm{h}$ of permeate. The brackish water was obtained by the mixture of the seawater and freshwater from the Pombas River until it reached the TDS concentration of $1,500 \pm 100 \mathrm{mg} / \mathrm{L}$. The operating time was 3 hours per day, given by the volume of the feed water storage tank. Coagulant, polyaluminium chloride, was used prior to the UF system to lower the $\mathrm{pH}$ to $6.0-6.5$ in order to form small flocs to be removed during the treatment. The UF membrane backwash was done automatically every 30 minutes during 30 seconds, the acid and basic backwash of the UF membrane was done when necessary. A centrifugal pump brought the water to the RO system from the tank of the UF permeate. The pretreated water passed by a disk filter was pumped by the pressure pump to the softening system. Sodium metabisulfite was added to protect the membranes for eventual residual chlorine. Before flowing to the $\mathrm{RO}$ membranes, the water passed through a cartridge filter. The RO system was operated in two stages and single pass. RO permeate passed through the UV disinfection was stored in a tank of 5,000 L, whereas the brine was stored in another tank of 5,000 L. Brine was used in other experiments, not reported in this paper, with constructed wetlands. In total 34 experiments were carried out during one year of operation and at the end of each experiment CIP was conducted with the permeate from the RO system was carried out.

Table 1. Characteristics of the UF and RO membranes.

\begin{tabular}{c|c|c}
\hline Characteristics & $\begin{array}{c}\text { UF membrane } \\
\text { Pentair X - Flow Aquaflex } \\
55[6]\end{array}$ & $\begin{array}{c}\text { RO membranes } \\
\text { Vontron LP21 - 4040 [7,8] }\end{array}$ \\
\hline Type & $\begin{array}{l}\text { Hydrophilic membrane } \\
\text { composed of a blend of }\end{array}$ & $\begin{array}{c}\text { Aromatic polyamide } \\
\text { compound }\end{array}$ \\
\hline
\end{tabular}




\begin{tabular}{c|c|c}
\hline & $\begin{array}{c}\text { polyvinylpyrrolidone and } \\
\text { polyethersulfone }\end{array}$ & - \\
\hline Structure & $20 \mathrm{~nm}$ & - \\
\hline Nominal pore size & $55 \mathrm{~m}^{2}$ & $4 \mathrm{~m}^{2}(\mathrm{x} \mathrm{5} \mathrm{membranes})$ \\
\hline Area & - & $\leq 40^{\prime \prime}$ \\
\hline Diameter & - & - \\
\hline Length & $30^{\circ} \mathrm{C}$ & - \\
\hline Temperature & $3 \mathrm{bar}$ & $41 \mathrm{bar}$ \\
\hline $\begin{array}{c}\text { Max. } \\
\text { transmembrane } \\
\text { pressure }\end{array}$ & - & $4-10$ \\
\hline $\begin{array}{c}\text { Max. backflush } \\
\text { pressure }\end{array}$ & $2-12$ & - \\
\hline $\begin{array}{c}\text { Max. working } \\
\text { pressure }\end{array}$ & $<3$ & - \\
\hline $\begin{array}{c}\text { pH of the feed } \\
\text { water }\end{array}$ & $<0.1 \mathrm{NTU}$ & $99.5 \%$ \\
\hline SDI & - & $75 \%$ \\
\hline Turbidity & - & \\
\hline $\begin{array}{c}\text { Average rejection } \\
\text { of salts }\end{array}$ & & \\
\hline $\begin{array}{c}\text { Medium recovery } \\
\text { rate }\end{array}$ & & \\
\hline
\end{tabular}

\subsection{Water Quality Parameters}

After the beginning of the operation system, three water samples were collected in four different points of the system (Fig. 2) to analyze the following parameters: $\mathrm{pH}$, temperature, turbidity, apparent color, TDS, electrical conductivity (EC), alkalinity, total hardness, chloride, sulfate and, calcium. In addition to the sampling points in the pilot plant, the freshwater from the Pombas River and sea water were also characterized. The water analysis methods are described in [9], while Table 2 shows the equipment for the analyses. Results are shown in four water sampling points: brackish water (feed water), UF permeate, RO permeate and, brine (Fig.2). In total there were 102 samples collected during the whole experimental period.

Table 2. Methods and equipment used for determination of water quality in the desalination pilot plant.

\begin{tabular}{|c|c|c|c|}
\hline Parameter & Method & Equipment & Accuracy \\
\hline $\mathrm{pH}$ & Potentiometric & $\begin{array}{c}\text { pHmeter PG2000 } \\
\text { GEHAKA }\end{array}$ & $\pm 0.02 \%$ \\
\hline Temperature $\left({ }^{\circ} \mathrm{C}\right)$ & Thermometer* & Ultrameter II Myron & $\pm 1 \%$ \\
\hline Turbidity (NTU) & Nephelometric & $\begin{array}{c}\text { Turbidimeter 2100Q } \\
\text { HACH }\end{array}$ & $\pm 3 \%$ \\
\hline Apparent color $(\mathrm{uH})$ & Colorimetric & DM Digimed & $\pm 1 \%$ \\
\hline TDS (mg/L) & Compensation* & Ultrameter II Myron & $\pm 1 \%$ \\
\hline $\begin{array}{l}\text { Electrical conductivity } \\
(\mu \mathrm{S} / \mathrm{cm})\end{array}$ & Electrolysis* & Ultrameter II Myron & $\pm 1 \%$ \\
\hline Alkalinity $\left(\mathrm{mg} / \mathrm{L} \mathrm{CaCO}_{3}\right)$ & Titrimetric & Burette & - \\
\hline $\begin{array}{c}\text { Total hardness }(\mathrm{mg} / \mathrm{L} \\
\left.\mathrm{CaCO}_{3}\right)\end{array}$ & Titrimetric & Burette & - \\
\hline
\end{tabular}




\begin{tabular}{clll}
\hline Chloride $(\mathrm{mg} / \mathrm{L})$ & Titrimetric & Burette & - \\
\hline Sulfate $(\mathrm{mg} / \mathrm{L})$ & Titrimetric & Burette & - \\
\hline Calcium $(\mathrm{mg} / \mathrm{L})$ & Titrimetric & Burette & - \\
\hline
\end{tabular}

*The conductivity measurements were standardized at $25^{\circ} \mathrm{C}$ by the equipment. To perform temperature compensation, the instrument measures the temperature of the sample and makes correction on an internal microprocessor that has data derived from known chemical solutions. TDS data are a function of the compensated conductivity measurement.

\subsection{System Efficiency, operational control}

In order to evaluate the efficiency of the pilot system, we also obtained data on filtration rate, osmotic pressure, recovery rate and the mass balance.

Filtration rate is the amount of a quantity that transpasses a surface per unit of time and area (Eq. 1):

$\phi=\frac{\left(v_{p} / t\right)}{n_{m} \cdot A_{m}}$

where $\phi$ is the permeate filtration rate $\left(\mathrm{L} / \mathrm{h} / \mathrm{m}^{2}\right), V_{p}$ is the permeate volume (L), $t$ is the time (h), $n_{m}$ is the number of membrane elements, and $A_{m}$ is the surface area of the membrane element $\left(\mathrm{m}^{2}\right)$.

To determine the mass balance, samples were collected in a single experiment at eight points of the system, which are: coagulated brackish water, UF permeate, UF permeate stored in the tank, UF reject, UF permeate before the softening system, RO concentrate, and RO permeate (after passing through the membranes and UV disinfection). For this experiment, triplicate water samplings were taken to measure the concentrations of TDS, temperature, and electrical conductivity.

Mass balance calculations were done with the aid of an Excel spreadsheet program. In order to facilitate the understanding and calculation of the balance, a signal convention was adopted, thus, the flow that was supplied to the system (input) was considered positive and the flow that was withdrawn or retained (output) of the system was considered negative. TDS values were obtained from the average of the three samples collected at each collection point of the system.

The recovery rate corresponds to the percentage of permeate being treated from the inlet flow. This is obtained by the relation between the permeate $\left(Q_{p}\right)$ and feed water $\left(Q_{\text {feed }}\right)$ flow rate. Osmotic pressure is the pressure exerted on the feed solution in contact with the membranes providing balance between the concentration gradient and the pressure gradient, thereby allowing the passage of the solvent through the semipermeable membrane. The osmotic pressure $(\pi)$ in the RO depends on the solute concentration and the temperature, and can be estimated by the van't Hoff equation $[10,11]$ :

$\pi=\varphi \mathrm{CRT}$

where, $\pi$ is the osmotic pressure (bar), $\varphi$ is the osmotic coefficient, $C$ is the molar concentration of solute ions in solution ( $\mathrm{mol} / \mathrm{L}$ ), $R$ is the gas constant (atm.L/mol.K), and $T$ is the temperature $(\mathrm{K})$.

Eq. (2) only holds for dilute salt solutions and temperatures close to $25 \mathrm{C}$. At significantly different conditions a more rigorous calculations, that takes into consideration ions activities rather than concentrations, has to be applied [12]. In order to obtain the transmembrane pressure data, readings were taken every 5 minutes of operation by means of the pressure meter installed in the RO system. The transmembrane pressure is defined as the pressure gradient of 
the membrane, or the average feed pressure minus the permeate pressure. The feed pressure is often measured at the initial point of a membrane module [11].

\section{Results}

The water quality results presented here refer to 34 non-consecutive operation days of sampling during the experiments. Table 3 shows the variation of the water quality of Pombas River during the period of the experiments.

Table 3. Variation of the water quality parameters in the Pombas River.

\begin{tabular}{cc}
\hline Parameters & Range \\
\hline $\mathrm{pH}$ & $5.59-6.76$ \\
Turbidity $(\mathrm{NTU})$ & $2.1-14.5$ \\
Apparent color $(\mathrm{uH})$ & $5.2-153.0$ \\
TDS $(\mathrm{mg} / \mathrm{L})$ & $21.5-53.3$ \\
Electrical conductivity $(\mu \mathrm{S} / \mathrm{cm})$ & $34.0-84.3$ \\
Temperature $\left({ }^{\circ} \mathrm{C}\right)$ & $19.0-26.3$ \\
\hline
\end{tabular}

Apparent color of the Pombas river water varied the most with the seasonal variations. Higher values were observed in dry periods, mainly in May and June 2017, when there are not heavy rains. Despite the influence of the high tides, the water quality of the Pombas River was not affected by the sea water intrusion during the period of the experiments, presenting low TDS and EC concentrations.

\subsection{Coagulant dosage and coagulation $\mathrm{pH}$}

The main objective of using coagulation before UF in this study was to protect the membranes. As we used freshwater from the river to prepare brackish water, the concern was to avoid the fouling of the membranes.

Fig. 3 shows the variation of coagulant dosage, coagulation $\mathrm{pH}$, and turbidity of the brackish water, and UF and RO permeates during the experiments. It can be observed that the UF system presented better turbidity removal with $\mathrm{pH}$ and coagulant dosage values close to 6.4 and $15 \mathrm{mg} / \mathrm{L}$, respectively. Therefore, the coagulation was a fundamental pretreatment step for the retention of solids in the UF membrane.

The coagulation $\mathrm{pH}$ was measured after the disk filter of the UF system and before the UF membrane (Fig. 2). The coagulation $\mathrm{pH}$ variation $(6.0-7.0)$ depended on the coagulant dosage. High coagulant dosage $(>15 \mathrm{mg} / \mathrm{L})$ led to lower coagulation $\mathrm{pH}(<6.5)$ and vice versa. The dosage control of the coagulant was done by a metering pump, which depended on the turbidity, color and, temperature of the brackish water. Experiments were done in different periods of the year which explains the great variation showed in Fig. 3. However, there was a greater stability in the dosage of the coagulant starting from the fifteenth day (Fig. 3). 


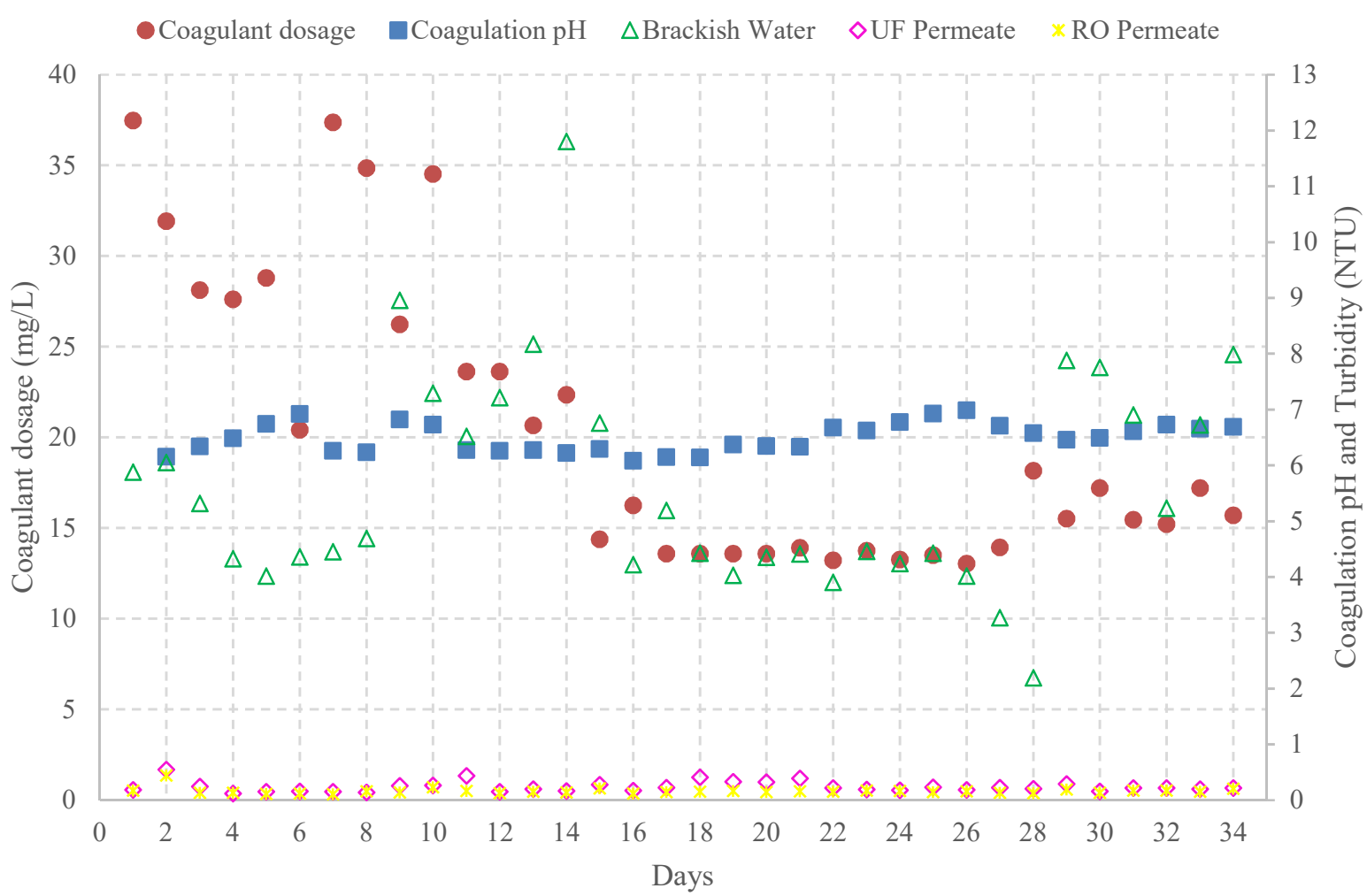

Fig. 3. Variation of coagulation $\mathrm{pH}$, coagulant dosage, and turbidity in the brackish water, UF and RO permeates.

\subsection{Water Quality Evaluation}

\subsubsection{Brackish water}

The quality of brackish water (feed water) is presented in Table 4. The apparent color of the brackish water (Fig. 4) was influenced by the water quality of the river which varied according to the seasons and presented higher values during the winter. The highest standard deviation was for chloride. The brackish water quality variation was due to the variation of the water quality of the Pombas river, which was mixed with the seawater to produce the feed water.

Table 4. Brackish water quality in the desalination pilot plant.

\begin{tabular}{|c|c|c|c|c|}
\hline Parameter & Minimum & Maximum & Average & Standard Deviation \\
\hline $\mathrm{pH}$ & 6.5 & 8.2 & 7.0 & 0.4 \\
\hline Temperature $\left({ }^{\circ} \mathrm{C}\right)$ & 19.0 & 28.1 & 22.6 & 2.1 \\
\hline Turbidity (NTU) & 2.2 & 11.8 & 5.6 & 2.0 \\
\hline Apparent color $(\mathrm{uH})$ & 4.3 & 135.7 & 35.4 & 44.0 \\
\hline TDS $(\mathrm{mg} / \mathrm{L})$ & 1,432 & 1,589 & 1,492 & 43.5 \\
\hline Electrical conductivity $(\mu \mathrm{S} / \mathrm{cm})$ & 1,980 & 2,203 & 2,063 & 58.7 \\
\hline Alkalinity $\left(\mathrm{mg} / \mathrm{L} \mathrm{CaCO}_{3}\right)$ & 5.3 & 18.7 & 12.3 & 3.6 \\
\hline Total hardness $\left(\mathrm{mg} / \mathrm{L} \mathrm{CaCO}_{3}\right)$ & 108.0 & 232.2 & 195.3 & 29.6 \\
\hline Chloride $(\mathrm{mg} / \mathrm{L})$ & 507.9 & 924.8 & 620.9 & 111.4 \\
\hline Sulfate $(\mathrm{mg} / \mathrm{L})$ & 91.8 & 218.6 & 122.5 & 36.5 \\
\hline Calcium $(\mathrm{mg} / \mathrm{L})$ & 35.4 & 58.0 & 41.1 & 5.7 \\
\hline
\end{tabular}




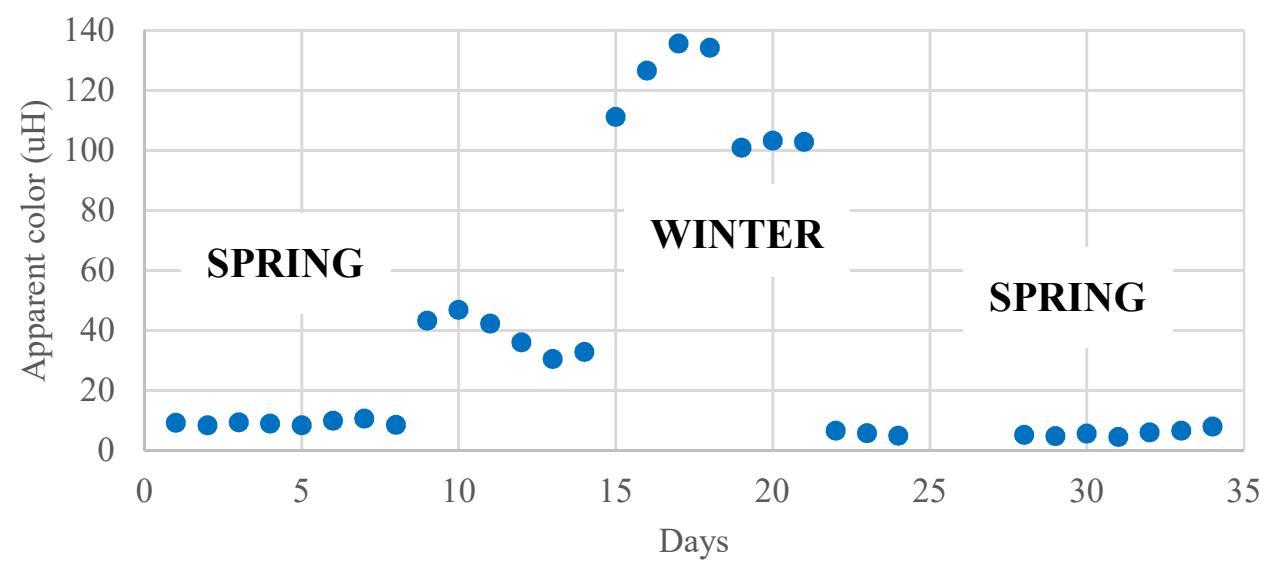

Fig. 4. Apparent color variation of the influent brackish water to the desalination pilot plant, during 34 non-consecutive operation days.

\subsubsection{Removal efficiency}

The pilot desalination system presented high removal efficiency of TDS and electrical conductivity as shown in Figs. 5 and 6. There was not significant difference of TDS and electrical conductivity (EC) concentrations between brackish and UF permeate. The variation of TDS in RO permeate was 7.21 and $15.82 \mathrm{mg} / \mathrm{L}$ with removal efficiency of $99.4 \%$. TDS concentrations of brine were 2 times higher than the concentrations of brackish water.

Similarly, electrical conductivity (EC) was removed by the RO system, with efficiency of $99.3 \%$, with minimum of $11.7 \mu \mathrm{S} / \mathrm{cm}$ and maximum of $29.6 \mu \mathrm{S} / \mathrm{cm}$ in the RO permeate. The temperature of the samples did not vary and remained close to the ambient temperature between 18 and $28.9^{\circ} \mathrm{C}$.

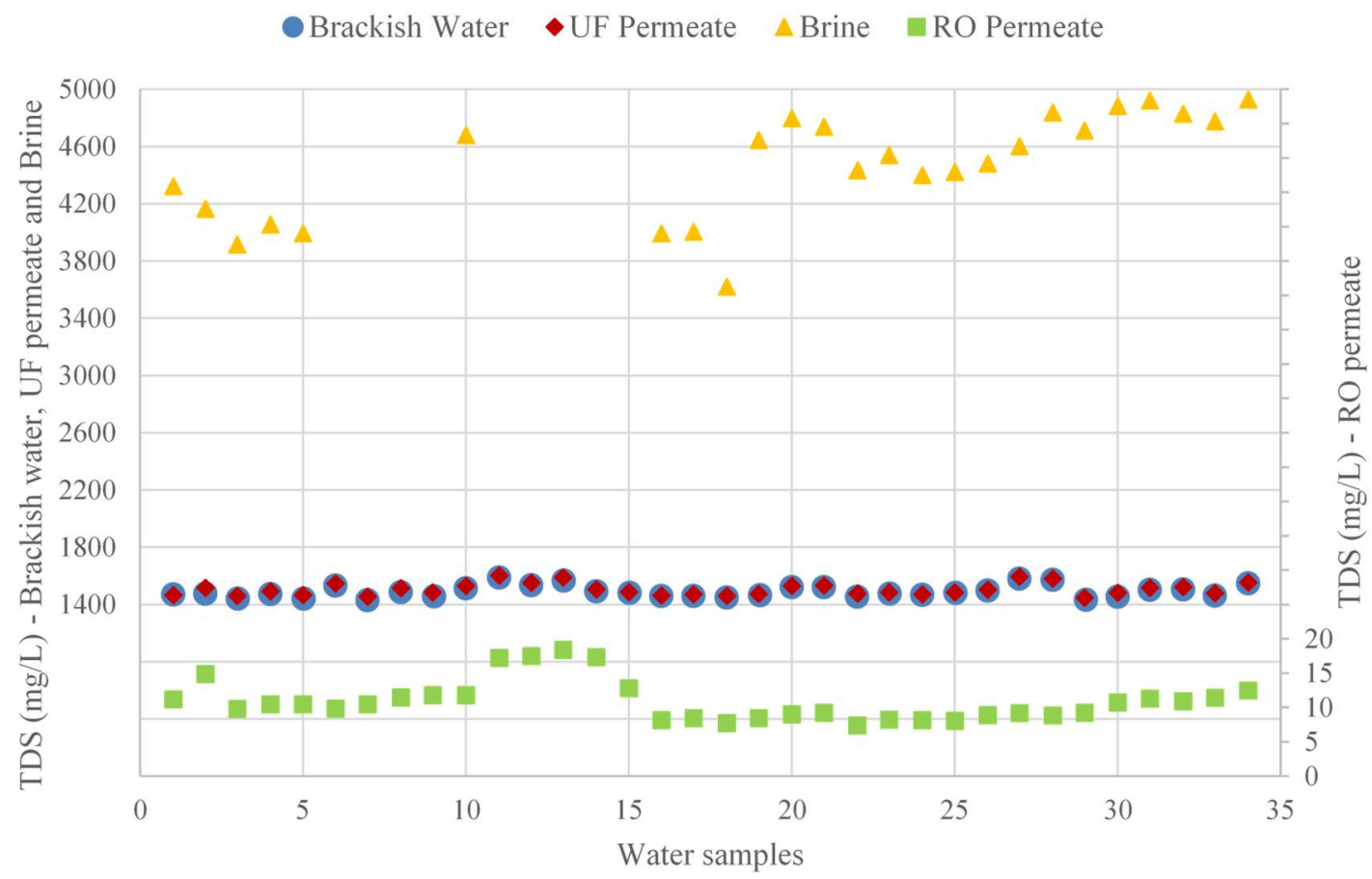

Fig. 5. Variation of the average of TDS concentration in samples taken from brackish water, UF permeate, RO permeate and, brine. 


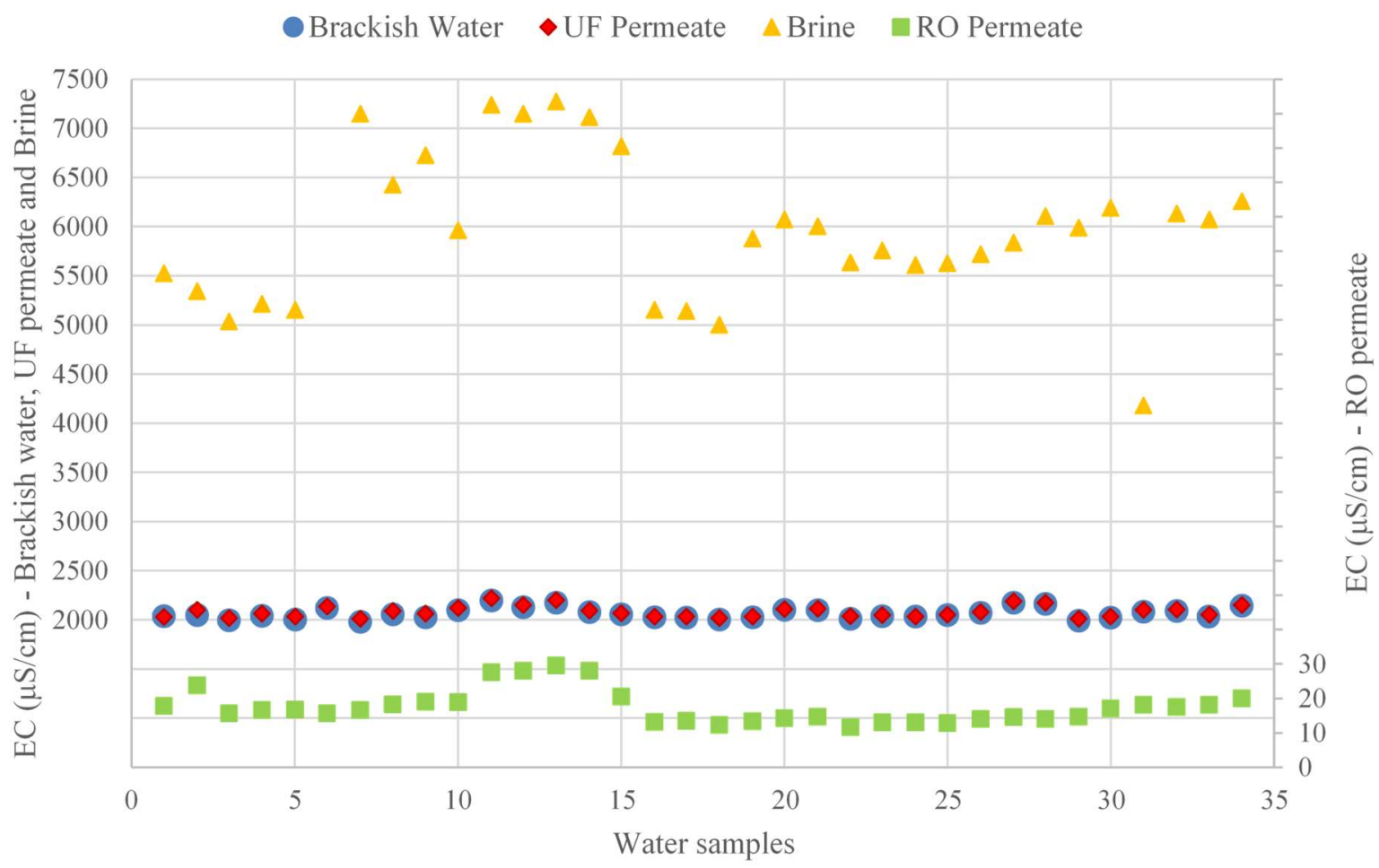

Fig. 6. Variation of the average of electrical conductivity concentration in samples taken from brackish water, UF permeate, RO permeate and, brine.

Fig. 7 shows the variation of turbidity, apparent color, $\mathrm{pH}$, alkalinity, total hardness, calcium, chloride and sulfate in the brackish water, UF permeate, RO permeate and brine samples, during the experiments. The brackish water turbidity varied from 2.2 to 11.8 NTU, with average of 5.63 NTU (Fig. 7a). The turbidity of UF and RO permeates and, brine presented turbidity less than 0.6, 0.5 and, $1.2 \mathrm{NTU}$, respectively. UF and RO membranes removed the turbidity from the brackish water, mainly in the UF system showing the importance of the pre-treatment in the removal of suspended and dissolved solids. Overall, the removal efficiencies in the UF system were $96.4 \%$ and $98.6 \%$ of turbidity and color respectively. Turbidity was not concentrated in the brine; therefore, it was removed during the membrane backwashes.

The same occurred with apparent color (Fig. 7b). However, the apparent color variation in the brackish water was greater $(4.6-135.7 \mathrm{uH})$ than turbidity, with average of $35.4 \mathrm{uH}$. The maximum values in the UF permeate, RO permeate and, brine was 3.6, 0.6 and, 8.5 respectively.

$\mathrm{pH}$ variation was very similar in the brackish water and brine, with mean value of 7.0, in the UF and RO permeates as well, with mean value of 5.9 (Fig. 7c).

The brackish water presented alkalinity variation from 5.3 to $18.7 \mathrm{mg} / \mathrm{L} \mathrm{CaCO}_{3}$, with average of $12.3 \mathrm{mg} / \mathrm{L} \mathrm{CaCO}_{3}$ (Fig. 7d). The alkalinity variation in the UF permeate was $2.0-13.5 \mathrm{mg} / \mathrm{L} \mathrm{CaCO}_{3}$, while in the $\mathrm{RO}$ permeate $0.7-2.0 \mathrm{mg} / \mathrm{L} \mathrm{CaCO}_{3}$. The alkalinity was concentrated in the brine $\left(4.0-29.2 \mathrm{mg} / \mathrm{L} \mathrm{CaCO}_{3}\right)$ with mean value of $16.8 \mathrm{mg} / \mathrm{L}$ $\mathrm{CaCO}_{3}$.

The desalination pilot system was able to remove completely the total hardness, as observed in Fig. 7e. Total hardness variation in the brackish water $(108.0-232.2 \mathrm{mg} / \mathrm{L}$ $\left.\mathrm{CaCO}_{3}\right)$ and UF permeate was very similar $\left(130.6-234.5 \mathrm{mg} / \mathrm{L} \mathrm{CaCO}_{3}\right)$. There was 
greater total hardness variation in the brine, due to the regeneration cycles of the softening system which sent the salts to the brine tank.

Fig. $7 \mathrm{f}$ shows the variation of calcium in the brackish water $(35.4-58.0 \mathrm{mg} / \mathrm{L})$ similar to the UF permeate $(31.6-52.7 \mathrm{mg} / \mathrm{L})$. Calcium was completely removed in the RO system, with accumulated concentrations in the brine.

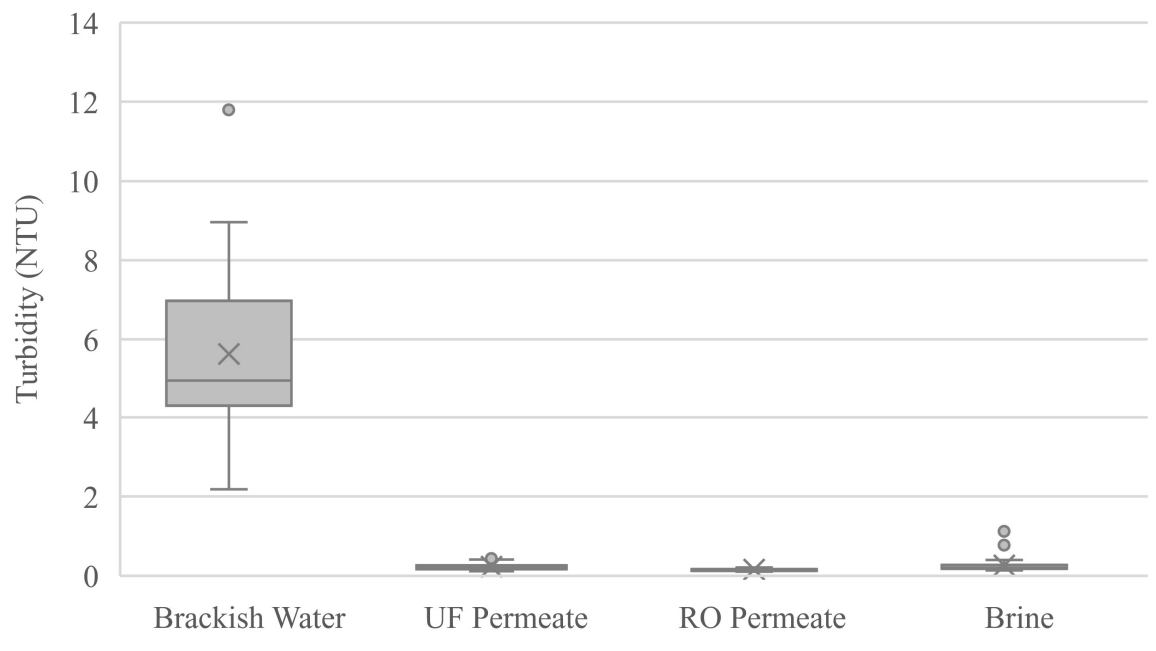

(a)

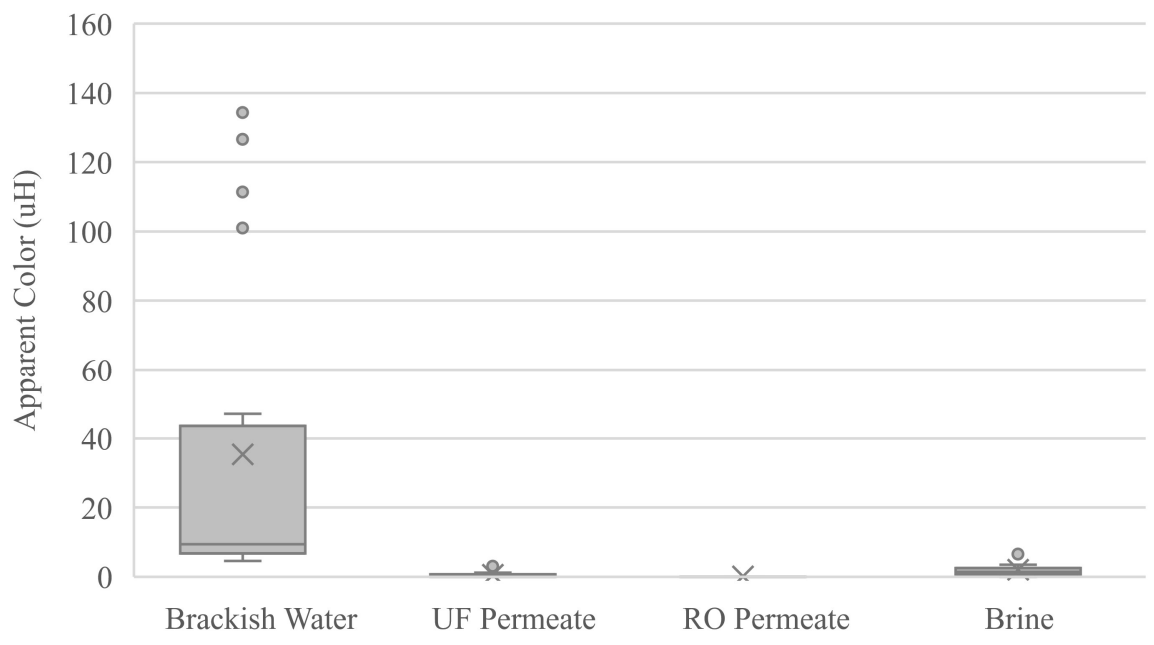

(b) 


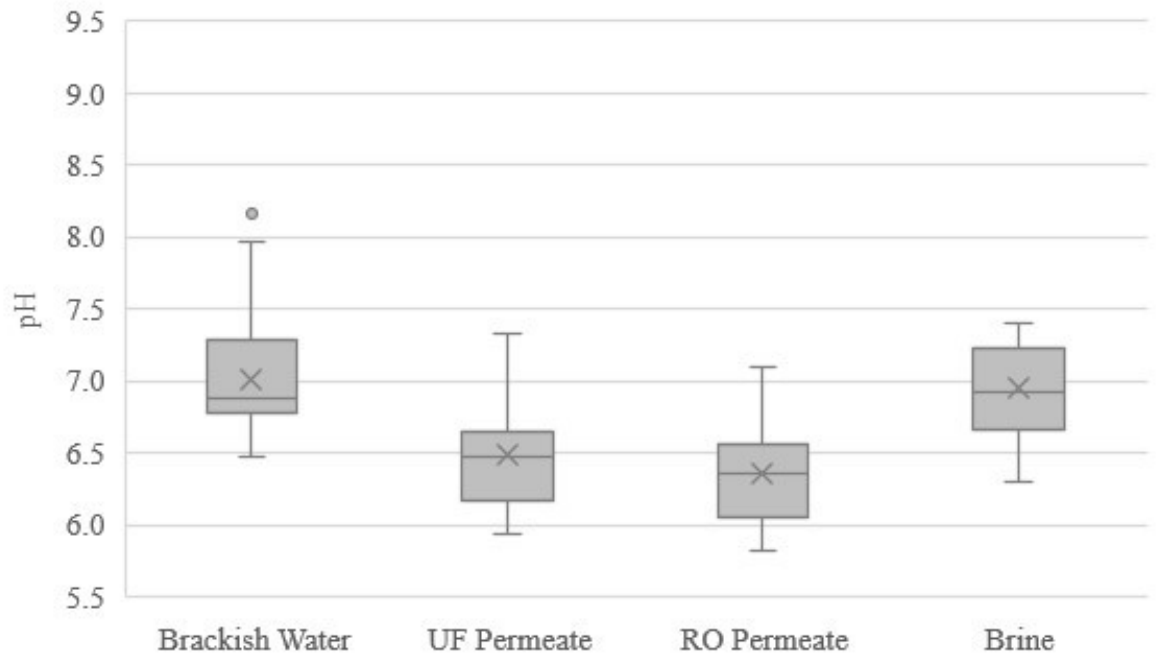

(c)

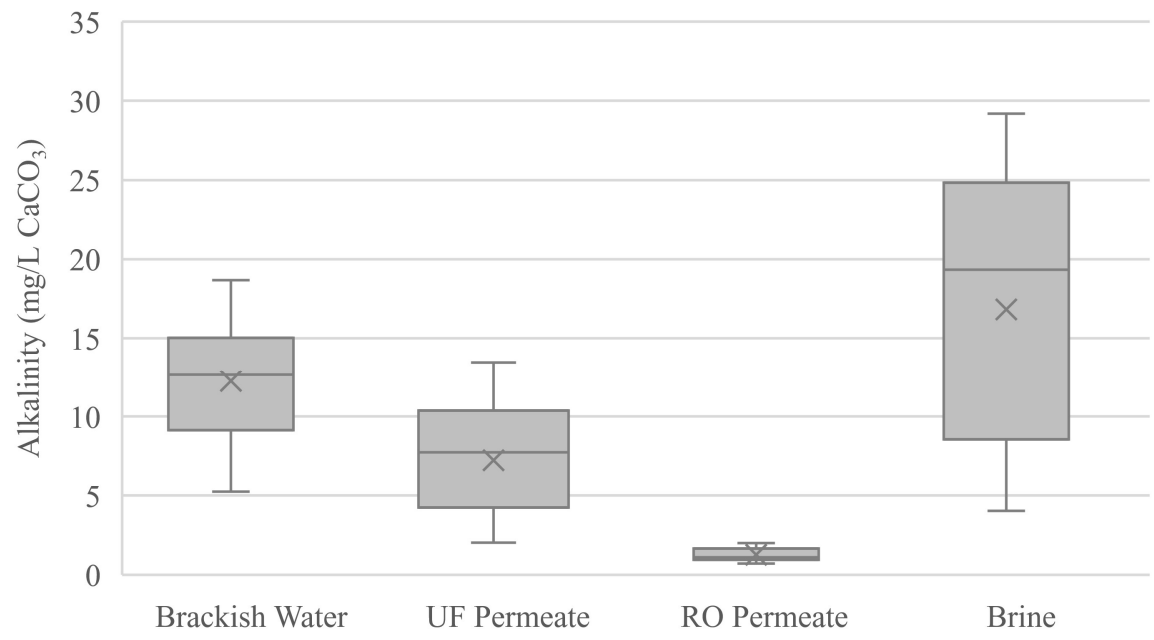

(d)

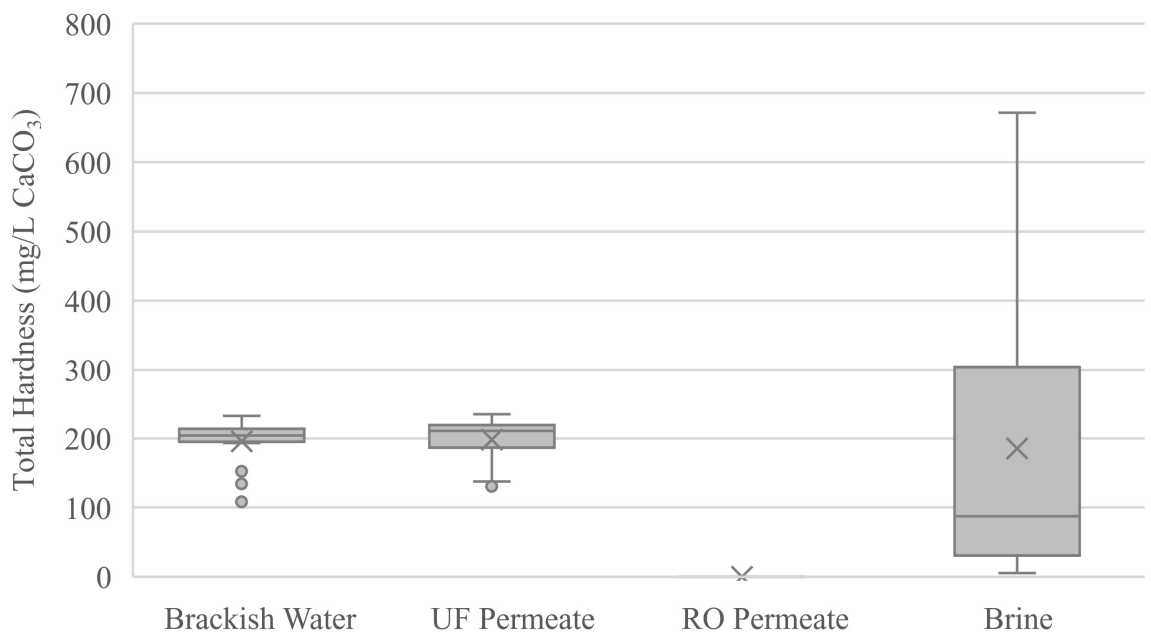

(e) 


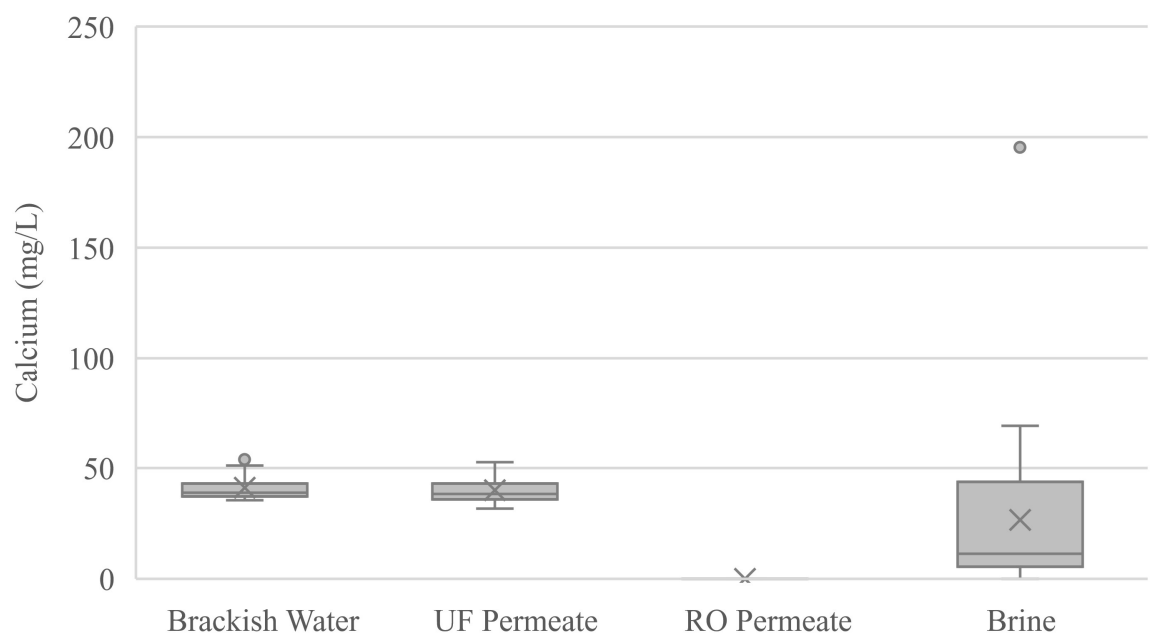

(f)

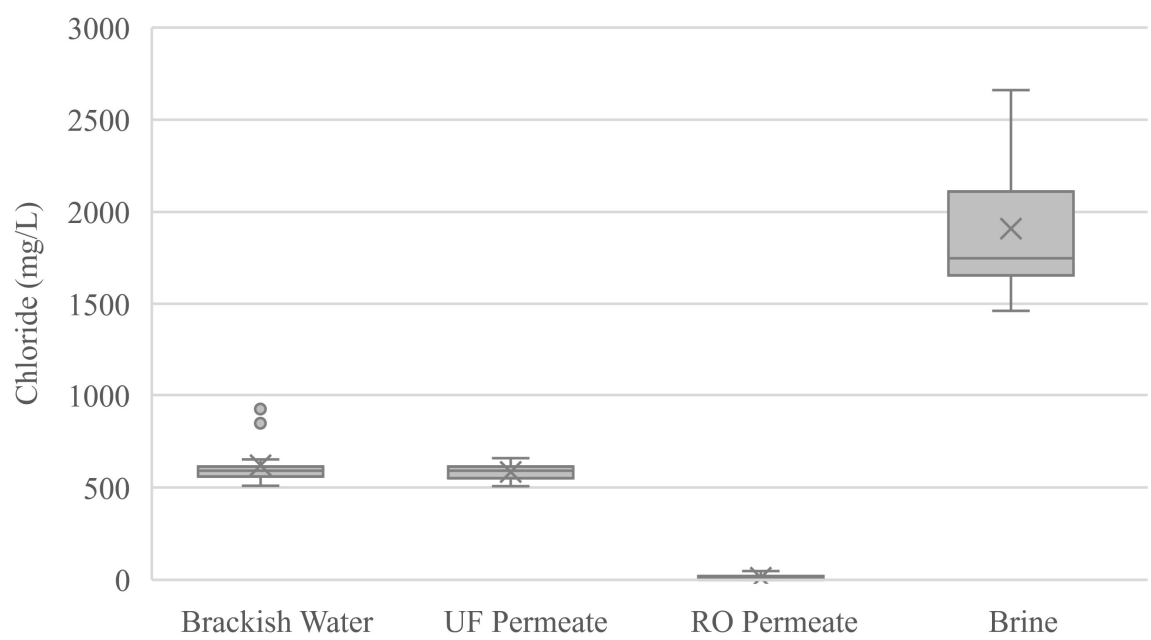

(g)

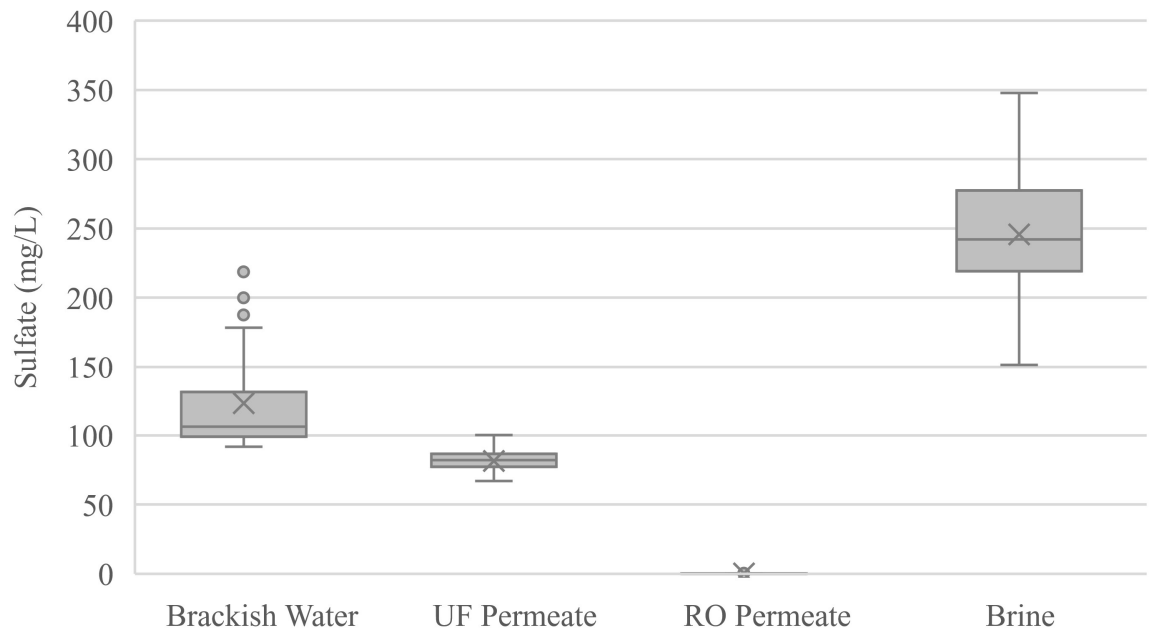


Fig. 7. Empirical distribution of the results for the water quality parameters evaluated in the desalination pilot plant. (a) Turbidity; (b) Apparent color; (c) pH; (d) Alkalinity; (e) Total hardness; (f) Calcium; (g) Chloride; (h) Sulfate.

Chloride variation was similar in the brackish water and UF permeate (Fig. $7 \mathrm{~g}$ ). It was removed in the RO membrane and concentrated in the brine, with variation of $1,462.5$ $-2,659.7 \mathrm{mg} / \mathrm{L}$.

Sulfate concentrations were lower when compared to chloride (Fig. 7h). Brackish water variation was $91.8-218.6 \mathrm{mg} / \mathrm{L}$. Sulfate variations in the UF permeate, RO permeate and brine were $67.1-100.3 \mathrm{mg} / \mathrm{L}, 0-6.1 \mathrm{mg} / \mathrm{L}$ and $151.4-347.8 \mathrm{mg} / \mathrm{L}$, respectively. RO system was efficient to remove sulfate.

\subsection{Operational Parameters}

\subsubsection{Mass Balance}

Fig. 8 shows the flow chart of the mass balance of the pilot desalination system. The water volumes were measured before each operational process point indicated by letters and water samples were collected for analysis of TDS indicated by numbers. The positive and negative values represent the entrance and exit respectively of the mass balance. 


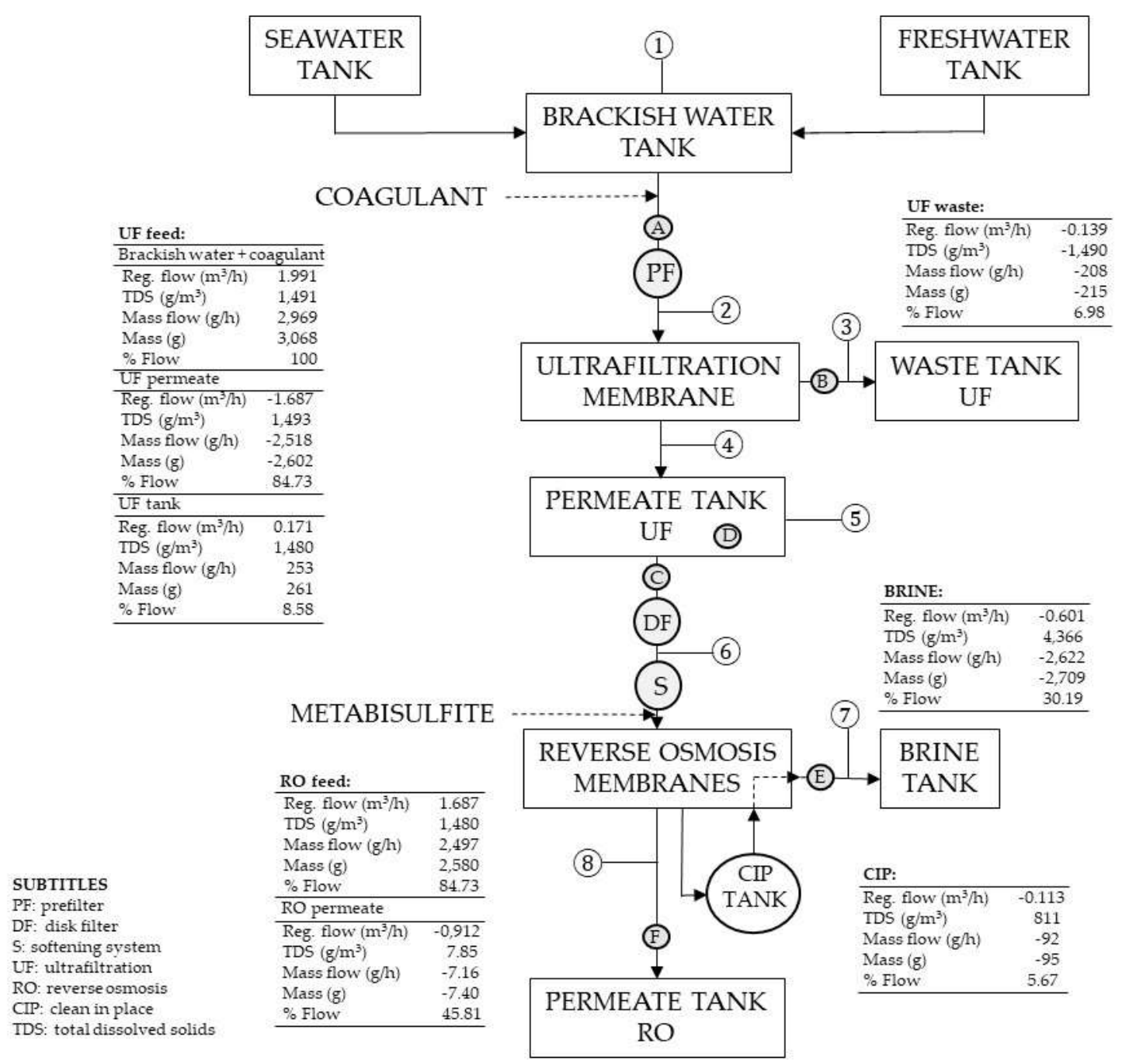

Fig. 8. Flow chart of the system with the mass balance in the desalination pilot plant.

The regulated water inlet flow in the UF system was $1.991 \mathrm{~m}^{3} / \mathrm{h}$, with $1491 \mathrm{~g} / \mathrm{m}^{3}$ of TDS (brackish water + coagulant). From this inlet flow, 6.98\% were used to backwash the UF membrane.

The inlet flow of the RO was $1.687 \mathrm{~m}^{3} / \mathrm{h}$, where $0.601 \mathrm{~m}^{3} / \mathrm{h}(30.19 \%)$ were sent to the brine tank and $0.113 \mathrm{~m}^{3} / \mathrm{h}(5.67 \%)$ were used for cleaning the RO membranes. The TDS concentration of the brine was $4,366 \mathrm{~g} / \mathrm{m}^{3}$, being about three times bigger than the TDS concentration of the brackish water. Therefore, the mass discharge of the brine was $2,622 \mathrm{~g} / \mathrm{h}$. The TDS concentration of $811 \mathrm{~g} / \mathrm{m}^{3}$ was retained inside the RO membrane and was discharged during the CIP, corresponding to a mass discharge of $92 \mathrm{~g} / \mathrm{h}$.

Studies are being conducted with solar panels connected to the pilot plant and to the grid, to verify how much energy is necessary to power the pilot desalination plant. In the future, with a mass and energy balances will be possible to evaluate the energy cost of operation, and therefore determine the feasibility to use the system to treat the salt rich water, before it reaches the consumer. 
Fig. 9 shows the variation of osmotic pressure, transmembrane pressure and, recovery rate during the last 20 days of the system operation. The osmotic pressure varied from 8.2 to 9.1 bar, with average of 8.7 bar.

For those pressures the variation of the recovery rate was from 55.3 to $65.7 \%$, considering only the RO system. The volume of water was measured from other flow meters (Fig. 8) to obtain the mass balance. The average global recovery rate, considering the UF and RO systems, from the results of flow rate obtained by the mass balance was $45.81 \%$.

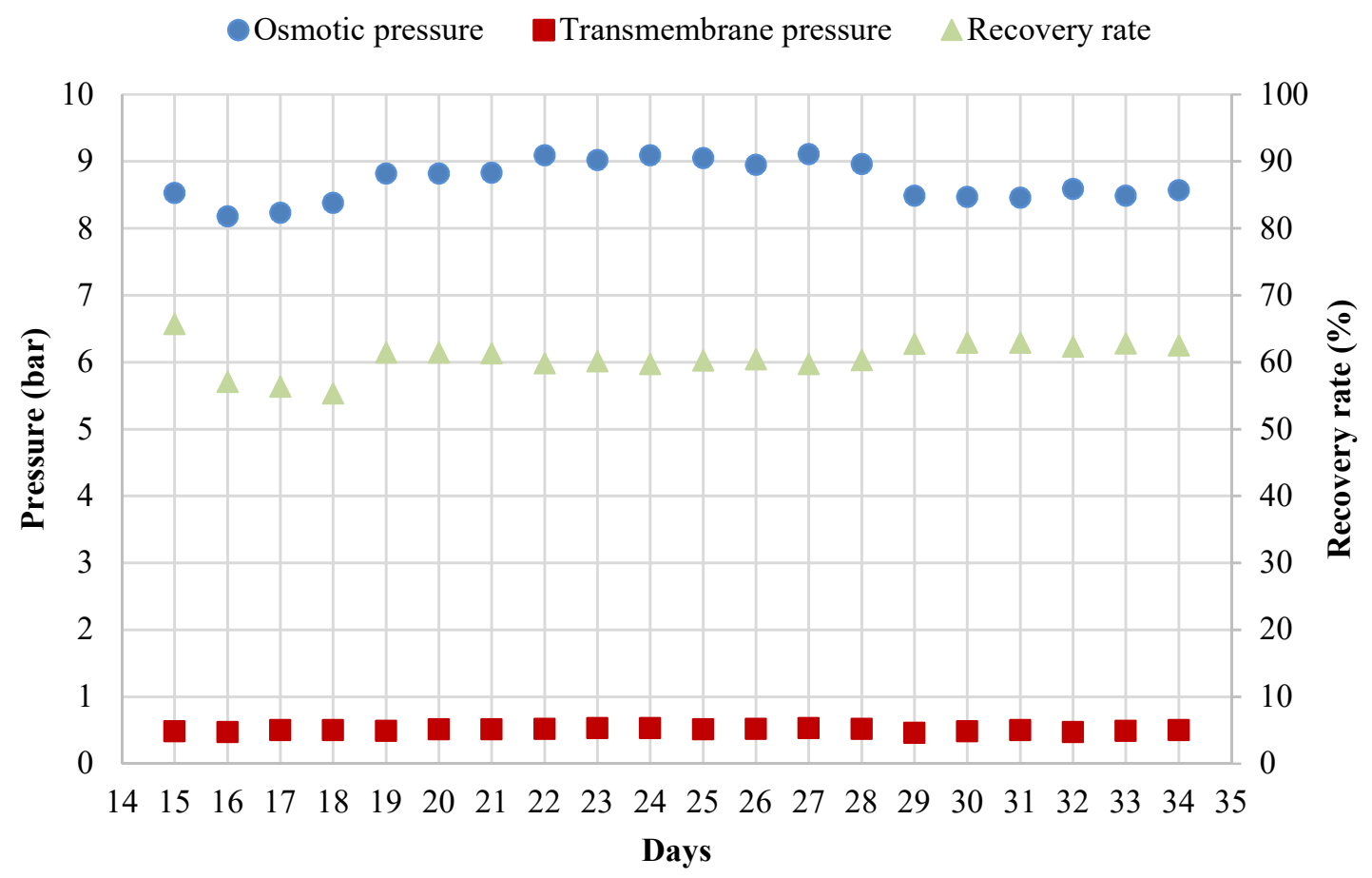

Fig. 9. Variation of osmotic and transmembrane pressures and, recovery rate during last 20 days of the system operation.

For the operation and functionality of the RO the applied pressures are substantially larger having to overcome load losses, transmembrane pressure, and promote solvent flow through the semipermeable membrane, in addition to the residual pressure to conduct the permeate to its destination. The pressure in the concentrate pipe remains high and forces the flow of the concentrate to the destination or, in some systems, to other reverse osmosis stages.

\section{Discussion}

\subsection{Water Quality}

Comparing with the natural brackish water quality from the semi-arid of Bahia, in Brazil [14], the brackish water we produced from the mixture of seawater and freshwater presented lower concentrations of total hardness and calcium.

Observing Fig. 7a and $7 \mathrm{~b}$, it is noted that despite the large apparent color variation $(4.3-135.7 \mathrm{uH})$ in the brackish water, the value maximum of turbidity was $10 \mathrm{NTU}$. The turbidity removal efficiency was $96.9 \%$. The apparent color removal efficiency $100 \%$. Results of coagulation with polyaluminium chloride show that it is important to adjust the 
dosage of coagulant to get better removal efficiency in the desalination system. Microfiltration and UF can be considered a good pretreatment method in seawater desalination and lead to higher quality for RO feed with optimized coagulant condition [15]. Use of UF pretreatment systems resulted efficient removal of suspended solids $[15,16]$ and they produced 50 to $80 \%$ less residual solids than that of conventional granular media filtration. However, UF systems generate 3 to $5 \%$ larger volume of waste backwash water than granular media filters [17]. A study showed that an adaptive coagulant dosing system can potentially reduce the required frequency of backwash of the UF membrane [18].

The maximum apparent color standard is $15.0 \mathrm{uH}$ and the minimum turbidity (more restricted) is $<0.5 \mathrm{NTU}$ for drinking water [19]. Therefore, the values of turbidity and apparent color obtained in all experiments were within the limits established by the legislations $[19,20,21]$. However, in real RO desalination plants, the permeate is usually post treated with the addition of the minerals with concentrations established by the local drinking water legislation.

$\mathrm{pH}$ remains relatively constant in relation to the water sample collection points. The $\mathrm{pH}$ values of the $\mathrm{RO}$ permeate (Fig. 7c) during the experimental period ranged from 5.8 to 7.1 . The mean value was 6.4 , indicating that the system needs post treatment with the addition of alkalizing to avoid corrosion of equipment and greater damage to pipes and tanks. The pH standard for drinking water is 6.5 to 8.0 [20], 6.5 to 8.5 [21] and, in Brazil drinking water can have $\mathrm{pH}$ between 6.0 to 9.5 [19], but the ideal $\mathrm{pH}$ of the desalinated water depends on the purpose of use. A study conducted in Palestine, where the quality of drinking water was evaluated for one year, from rainwater cisterns, groundwater from the distribution network, and desalinated water by RO concluded that almost all samples of desalinated water by $\mathrm{RO}$ had $\mathrm{pH}$ values below the limit of 6.5 [22]. The brackish water and brine presented the same average $\mathrm{pH}(7.0)$. With the coagulant addition the average $\mathrm{pH}$ reduced to 6.5 in the UF and RO permeates.

The average removal efficiency of alkalinity in the RO permeate relative to the system brackish water was $90.6 \%$. The highest variation of alkalinity was in brine samples, with 4.0 to $29.2 \mathrm{mg} / \mathrm{L} \mathrm{CaCO}_{3}$.

Fig. 7e shows the hardness was totally removed after the RO membranes. In Brazil, the maximum allowed value hardness for drinking water is $500 \mathrm{mg} / \mathrm{L}$ [19]. However, this value should be lower depending on the purpose of water use. In a pilot plant of RO desalination with production of $1 \mathrm{~m}^{3} /$ day in a remote Mexican community, the total hardness for desalinated water was $1.0 \mathrm{mg} / \mathrm{L}$ [23]. Depending on the interaction of other factors, such as $\mathrm{pH}$ and alkalinity, water with a hardness above approximately $200 \mathrm{mg} / \mathrm{L}$ may cause scale deposition in the treatment plants, distribution system, pipelines, and tanks within buildings [20]. Brine presented maximum total hardness of $671.17 \mathrm{mg} / \mathrm{L}$, while the inlet brackish water had hardness on average equal to $195.3 \mathrm{mg} / \mathrm{L}$. WHO states that the concentration of minerals in brine is usually 2 to 10 times higher than that of the source water and is function of the TDS of the source water and the plant recovery rate [17].

Regarding to the calcium (Fig. 7f), there was total removal in the RO permeate. The mean calcium concentration was $26.6 \mathrm{mg} / \mathrm{L}$ for the brine. Comparing with the study done in Mexico, the calcium concentration was $0.39 \mathrm{mg} / \mathrm{L}$ in the desalinated water, for the feed water with $527.1 \mathrm{mg} / \mathrm{L}$ [23].

According to Fig. $7 \mathrm{~g}$, there was no significant removal of chloride in the UF permeate. However, mean chloride removal in the RO permeate of $99.5 \%$ was obtained. Comparing the results with the limits for drinking water, the RO permeate had chloride 
concentration below the maximum allowed value of $250 \mathrm{mg} / \mathrm{L}[19,20,21]$, with average of $16.5 \mathrm{mg} / \mathrm{L}$. Similar to chloride, sulfate was only effectively removed by the RO (Fig. $7 \mathrm{~h})$. The maximum sulfate value allowed in drinking water is $250 \mathrm{mg} / \mathrm{L}$ [19,20,21].

Regarding to chloride and sulfate, there were higher concentrations of chloride than sulfate. The removal efficiency in the RO system was significant for both parameters, $99.5 \%$ for chloride and $100 \%$ for sulfate.

Brine presented low turbidity and color, indicating that the retention of the suspended solids was effective within the membrane. UF membranes can provide product water with consistently low turbidity and silt density index (SDI) levels, regardless of brackish and seawater quality $[15,16]$. It presented variation from 1462.5 to $2659.7 \mathrm{mg} / \mathrm{L}$ of chloride and 151.4 to $347.8 \mathrm{mg} / \mathrm{L}$ of sulfate.

Data from chemical composition of brine produced from up to nine inland brackish water RO plants on the Arabian Peninsular (Oman, United Arab Emirates, and Saudi Arabia) were compiled [24]. The data indicated that these plants tend to produce brine of higher conductivity and TDS than a plant in Australia. This is possibly related to the feed water characteristics and variable plant operational parameters such as membrane type and flux. Depending on regional geochemistry, groundwater softening plants concentrate contain dissolved minerals such as calcium, magnesium, sodium, potassium, chloride, sulfate, silica, fluoride, nitrate and iron [24].

\subsection{Operational Parameters}

According to the mass balance, the flow of the RO permeate was $0.912 \mathrm{~m}^{3} / \mathrm{h}$, corresponding to the recovery rate of $45.81 \%$ with mean osmotic pressure of 9.25 bar, with variation between 8.30 and 9.35 bar. The system presented higher recovery rate compared to the RO desalination pilot system in Mexico, with flow rate of $0.12 \mathrm{~L} / \mathrm{s}$ and the RO membrane area was $7.246 \mathrm{~m}^{2}$, obtaining a recovery rate of $33 \%$ [23].

The manual of the RO system recommends working with 6 to 12 bar of the osmotic pressure [7], however the system was conditioned to operate between 7 and 10 bar. Therefore, the experiments were operated close to the maximum limit of osmotic pressure and TDS concentration of the brackish water $(1,600 \mathrm{mg} / \mathrm{L})$ [7]. The concentration of salts and the osmotic pressure are directly proportional, when there is higher concentration of salts, the osmotic pressure will be higher [11].

The desalination pilot system produced a mean flow rate of $1.08 \mathrm{~m}^{3} / \mathrm{h}$ of permeate and $0.50 \mathrm{~m}^{3} / \mathrm{h}$ of brine. The filtration rate varied from 27.1 to $30.4 \mathrm{~L} / \mathrm{h} \cdot \mathrm{m}^{2}$. The global mean recovery rate was $45.91 \%$. The osmotic pressure varied from 7.1 to 9.1 bar. The mean transmembrane pressure was 0.50 bar, which is recommended to be between 0.4 and 1.0 bar [11]. As in UF and MF, the RO operating at high flux or high transmembrane pressure leads to deposition of a thick fouling layer [25].

RO system performance and efficiency are dependent on source water quality (TDS, temperature, scaling compounds, etc.) and physical and chemical pretreatment. The level of pretreatment needed for successful operation is primarily a function of source water quality of solids, oxidizing agents, oil and grease, and temperature. The membrane material integrity is depended on various factors, including source water $\mathrm{pH}$, temperature, organic content, concentration of oxidants and oil and grease in the water, and solids content [17].

Although this work focused on the engineering design of the pilot plant, performance of the system, and water quality improvement, preliminary results of the experiments on 
the energy consumption show that the solar photovoltaic system produced $24 \%$ (data not shown) of the energy consumed by the pilot plant, corresponding to $5.34 \mathrm{~kW}$ to produce $1 \mathrm{~m}^{3}$ of RO permeate. The system consisted of 8 photovoltaic panels with capacity of $2000 \mathrm{Wp}$. Furthermore, preliminary results of brine disposal system by constructed wetlands using elephant grass indicated that the plants presented saturation and nutritional deficit from the fourth week of the experiments.

\section{Conclusions}

This is the first sustainable RO desalination pilot plant installed in Brazil to treat brackish water. The desalination plant produced water with high quality, presenting significant removal efficiency of all parameters analyzed. The main conclusions are:

- The UF pretreatment was effective in removing turbidity (96.9\%) and apparent color $(100 \%)$ of the brackish water while the RO system was highly effective in removing TDS (99.4\%) and electrical conductivity $(99.3 \%)$.

- Removal efficiencies of total hardness (100\%), alkalinity $(90.6 \%)$, sulfate $(100 \%)$, chloride $(99.5 \%)$, and calcium $(100 \%)$ were high in all experiments.

- Brine presented higher mean concentrations of TDS $(4872 \mathrm{mg} / \mathrm{L})$, electrical conductivity $(4180 \mathrm{mg} / \mathrm{L})$, alkalinity $(16.8 \mathrm{mg} / \mathrm{L} \mathrm{CaCO})$, sulfate $(245.7 \mathrm{mg} / \mathrm{L})$ and chloride $(1909.4 \mathrm{mg} / \mathrm{L})$ compared to the brackish water and UF permeate. Total hardness $\left(185 \mathrm{mg} / \mathrm{L} \mathrm{CaCO}_{3}\right)$ and calcium $(26.6 \mathrm{mg} / \mathrm{L})$ were lower due to the softening pretreatment. Turbidity and apparent color were removed during the UF membrane backwashes, thus were not concentrated in the brine.

- Coagulation with polyaluminium chloride showed that it is important to adjust the dosage of coagulant to get better removal efficiency in the desalination system.

- The water produced from the experiments (RO permeate) was not post treated to meet the mineral concentrations established by the legislation for drinking water.

- The desalination pilot plant produced water of high quality with mean recovery rate from the overall system (UF + RO) of $45.91 \%$ with osmotic pressure of 8.21 bar in the RO membranes. Considering only the RO system, the recovery rate varied from 55.3 to $65.7 \%$. The average filtration rate was $28.7 \mathrm{~L} / \mathrm{h} / \mathrm{m}^{2}$.

Funding: This research was funded by a Global Innovation Initiative (GII) grant managed by the Institute of International Education (IIE). GII is a program of the U.S. Department of State and the British Council.

Acknowledgments: The authors would like to thank to Water and Sanitation Company of Parana State (SANEPAR) who has provided the equipment and the facilities for carrying out the experiments and, to the Coordination of Superior Level Staff Improvement (CAPES) for the scholarship to the students.

\section{List of Symbols}

$\phi=$ permeate filtration rate $\left(\mathrm{L} / \mathrm{h} \cdot \mathrm{m}^{2}\right)$

$V_{p}=$ permeate volume $(\mathrm{L})$

$t=$ time $(\mathrm{h})$

$n_{m}=$ number of membranes (dimensionless)

$A_{m}=$ surface area of the membrane $\left(\mathrm{m}^{2}\right)$ 
$\pi=$ osmotic pressure (bar)

$\varphi=$ osmotic coefficient (dimensionless)

$C=$ molar concentration of solute ions in solution

$R=$ gas constant

$T=$ water temperature

\section{References}

1. L.T.L. Brito, M.S.B. Moura and G.F.B. Gama, Potencialidades da água de chuva no Semi-Árido brasileiro (Potentialities of rainwater in the Brazilian Semi-Arid), Embrapa Semi-Árido, Pernambuco, Brazil, 2007 (In Portuguese).

2. Em Discussão, Dessalinizar a água é cada vez mais viável (Water desalination is more feasible). Issue 23, Brazil, 2014 (In Portuguese).

3. Y. Rajavi, Water Desalination in the Middle East, 2013.

4. Instituto Brasileiro de Geografia e Estatística - IBGE (Brazilian Institute of Geography and Statistics), 2018 (In Portuguese). Available at: https://cidades.ibge.gov.br/brasil/pr/panorama.

5. Guia Geográfico do Paraná (Geographical Guide of Paraná), 2019 (In Portuguese). Available at: http://www.guiageo-parana.com/litoral.htm

6. Pentair, X-Flow Aquaflex 55, 2019. Available at: http://xflow.pentair.com/en/products/aquaflex

7. Permution, Manual técnico de operação e manutenção da unidade de tratamento avançado por osmose reversa (Technical Manual for Operation and Maintenance of the Advanced Reverse Osmosis Treatment Unit) - Modelo ROH $010054-1 \mathrm{~m}^{3} / \mathrm{h}$, Brazil, 2016 (In Portuguese).

8. Vontron, LP21-4040 Membrane Element, 2019. Available at: http://en.vontron.com/downloadRepository/6c0ad00f-5e5a-4f9e-8c4792d140915386.pdf

9. APHA, AWWA, WEF, Standard Methods for the Examination of Water and Wastewater, American Public Health Association, American Water World Association, 20 ed, 1999.

10. G.S. Monteiro, H.N. Silva and H.L.L. Lôbo, Simulação e análise de sistema de dessalinização via osmose Inversa: considerações para análise da qualidade da água (Simulation and analysis of desalination system using reverse osmosis: considerations for water quality analysis). Biosphere Encyclopedia, 5(2009), 1-12 (In Portuguese).

11. K.J. Howe, Princípios de Tratamento de Água (Principles of Water Treatment), Sao Paulo, Brazil, 2016 (In Portuguese).

12. J. Kucera, Desalination: Water from water, John Wiley \& Sons, New Jersey, 2014.

13. H.J. Yang, H.S. Kim, Effect of coagulation on MF/UF for removal of particles as a pretreatment in seawater desalination. Desalination, 247 (2009), 45-52.

14. J.S. Menezes, V.P. Campos and T.A.C. Costa, Desalination of brackish water for household drinking water consumption using typical plant seeds of semi arid regions. Desalination, 281 (2011), 271-277.

15. G. Pearce, S. Talo, K. Chida, A. Basha and A. Gulamhusein, Pretreatment options for large scale SWRO plants: case studies of UF trials at Kindasa, Saudi Arabia, and conventional pretreatment in Spain. Desalination, 167 (2004), 175-189.

16. D.F. Halpern, J. McArdle and B. Antrim, UF pretreatment for SWRO: pilot studies. Desalination, 182 (2005), 323-332.

17. WHO, Desalination for Safe Water Supply: Guidance for the Health and Environmental Aspects Applicable to Desalination, Public Health and the Environment, World Health Organization, Geneva, 2007. 
18. E. Hastuti and M.W. Wardiha, A study of brackish water membrane with ultrafiltration pretreatment in Indonesia's coastal area. Journal of Urban and Environmental Engineering, 6 (2012), n.1, 10-17.

19. Ministério da Saúde do Brasil (Brazil's Health Ministry), Portaria de Consolidação (Consolidation Ordinance) n. 5, Anexo XX - do controle e da vigilância da qualidade da água para consumo humano e seu padrão de potabilidade (Annex XX - control and monitoring of the water quality for human consumption and its potability standard) (Origen: PRT MS/GM 2914/2011), 2017 (In Portuguese).

20. U.S. Environmental Protection Agency, 2018 Edition of the drinking water standards and health advisories, 2018, 1-20.

21. WHO, Guidelines for Drinking-water Quality - Fourth Edition Incorporating the First Addendum, World Health Organization, 2017.

22. I. A. Al-Khatib and H. A. Arafat, Chemical and microbiological quality of desalinated water, groundwater and rain-fed cisterns in the Gaza strip, Palestine, Desalination, 249 (2009), 1165-1170.

23. H. Elasaad, A. Bilton, L. Kelley, O. Duayhe and S. Dubowsky, Field evaluation of a community scale solar powered water purification technology: A case study of a remote Mexican community application, Desalination 375 (2015), 71-80.

24. S.J. Khan, D. Murchland, M. Rhodes and T.D. Waite, Management of Concentrated Waste Streams from High-Pressure Membrane Water Treatment Systems. Critical Reviews in Environmental Science and Technology, 39 (2009), 367-415.

25. C. Fritzmann, J. Löwenberg, T. Wintgens and T. Melin, State-of-the-art of reverse osmosis desalination. Desalination, 216 (2007), 1-76. 